\title{
Recherches sur les brise-lames flottants destinés à réfléchir la houle en eau peu profonde
}

\section{Observations on floating breakwaters for reflection of shallow water waves}

\author{
PAR A. K. JOHNSTON \\ NEWCASTLE UNIVERSTYY COLLEGE, TIGHE'S HILL (N.S.W.) AUSTRAIIF \\ (suite et fin)
}

\begin{abstract}
La présente étude est née d'un problème d'érosion de plage. Etant donné que les houles cambrées érodent une plage alors que les houles peu cambrées l'engraissent, on envisagea, comme moyen de protection, la possibilité de réfléchir partiellement les ondes incidentes par des briselames flottants. Le but poursuivi était de réfléchir suffisamment d'énergie pour que les houles atteignant la côte soient construtives et non érosives.

Ce problème a été etudié théoriquement et expérimentalement en partant de l'hypothèse selon laquelle un brise-lames flottant doit, pour être efficace, réféchir approximativement $50 \%$ de l'énergie des ondes de toutes périodes jus$q u ' d \dot{\alpha} 10$ secondes. Les brise-lames flottants ne peluvent être amarrés rigidement, et, à l'origine, on a simplement utilisé leur inertie pour produire un effet réfléchissant. Des considérations d'ordre pratique concernant les dimensions des brise-lames conduisent à limiter la réflexion par inertie aux ondes ayant une période inférieure $\dot{a} 6$ secondes environ.

Pour passer aux ondes plus longues, on utilisa ici le phénomène de résonance, en réalisant un brise-lames sous forme d'un réservoir d'eau ouvert, de dimensions telles que la résonance propre de l'ean qu'il renferme tende à réfléchir les ondes plus longues.

Deux types adéquats de brise-lames flottants utilisant cette conjugaison de l'inertie et de la résonance, ont été mis au point et essayés sur un modèle réduit à l'échelle 1/120. Les résultats obtenus apparaissent nouveaux par rapport d̀ tous ceux obtenus jusqu'ici et font entrevoir la possibilité d'étendre leurs applications a d'autres fins que la protection des plages.
\end{abstract}

The present study arose from a problem of beach erosion. Since steep waves erode a beach and low camber waves build it up, the possibility of partial reflection of oncoming waves b!y floating barriers was considered as a means of protection. The objective was to reflect sufficient energy so that waves reaching the shore would be constructive rather than erosive.

This problem has been investigated theoretically and experimentally, starting with the premise that to be effective a floating barrier should reflect approximately $50 \%$ of the energy of waves of all periods up to 10 seconds. Floating barriers cannot be rigidly restrained and their earlier use has depended simply on their inertia for reflective effect. Practical considerations of barrier size limit inertia reflection to waves of less than about 6 seconds period.

To deal with the longer waves the phenomenon of resonance has here been employed by making the floating barrier an openended water container of such dimensions that the enclosed water tends to reflect the longer waves by its internal resonance.

Two successful designs of floating breakwater using this combination of inertia and resonance have been developed and tested on a model scale of 1 to 120. Their performance is shown to be an advance on anything hitherto achieved and their possible wider applications for purposes besides beach protection are indicated.

(1) Cit. Lat Houille Blanche, $\mathrm{n}^{\circ} 5,1958$, p. 540 . 


\section{Des facteurs intervenant dans l'étude d'un brise-lames flottant à résonance.}

Nous allons raisonner en partant du fait que ce qu'on cherche, c'est un brise-lames flottant, amarré dans 30 à 40 pieds $(9$ à $12 \mathrm{~m}$ ) de profondeur d'eau, et qui réfléchirait au moins $50 \%$ de l'énergie de toutes les vagues ayant des périodes inférieures à 10 secondes. C'est là un but assez modeste; néanmoins, un brise-lames de ce genre pourrait assurer grandement la protection d'une plage et permettre de nombreuses applications de ports provisoires. Selon l'analyse théorique qui précède, la réflexion de 50 \% de l'énergie des vagues correspondrait à un coefficient de transmission $a_{3} / a_{1}$ ne dépassant pas la valeur 0,7 pour toute houle de période inférieure à 10 secondes. Soit dit en passant, la valeur précitée est très proche de celle correspondant au minimum d'amplitude de la majorité des vagues; on devra donc la considérer comme la "profondeur optimum » pour l'action qu'on a en vue.

La recherche théorique précédente indique également qu'un résonateur unique ne présenterait pas une zone d'action suffisamment étendue pour remplir les conditions précédentes; si donc on n'avait recours qu'à la résonance pour obtenir la réflexion, on devrait utiliser plusieurs résonateurs accordés à des périodes différentes, comme l'a montré Valembois [3], mais ce serait impraticable avec un brise-lames flottant. Nous avons également montré précédemment que, dans le cas où l'inertie serait seule à provoquer la réflexion, les dimensions à donner au briselames deviendraient impossibles. Selon notre facon d'aborder le problème, on utilisera un briselames flottant, tirant parti des deux modes de réflexion : par la masse seule pour les ondes courtes et par sa forme en résonateur unique, accordé à ces ondes, pour les ondes plus longues.

En ce qui concerne la masse, le moyen le plus simple de la créer consiste à emprisonner le plus d'eau possible dans le brise-lames flottant. Les brise-lames que nous aurons à décrire sont en effet autant de réservoirs d'eau dont la masse propre n'est qu'une fraction de la masse efficace totale. L'équation (10) fournit un moyen d'estimer la masse nécessaire pour obtenir un effet de réflexion déterminé.

Ensuite, il y a lieu de considérer la forme à donner au brise-lames pour obtenir la réflexion par résonance. Considérons d'abord le cas d'un résonateur vertical (fig. 3) et supposons que l'on cherche à avoir pour le compartiment intérieur une période propre de résonance aussi grande que possible. En admettant l'expression simple $\mathrm{T}=2 \pi \sqrt{l / g}$ pour cette période propre, on obtient les valeurs suivantes pour la profondeur effective $l$ du compartiment :

\section{Factors in the design of floating resonant breakwater.}

It is now assumed as a basis for design that a floating breakwater is desired which will reflect at least $50 \%$ of the energy of all waves of periods less than 10 seconds, when moored in water between 30 and 40 feet deep. This is a fairly limited objective, but such a breakwater would serve well for most beach protection work and for many temporary harbour applications. In terms of the preceding theoretical analysis reflection of $50 \%$ of the ener'sy of waves would mean a transmission coefficient $a_{3} / a_{1}$ no greater than about 0.7 for any wave having a period less than 10 seconds. It might be remarked in passing that the depth suggested above is close to the value where most of the waves have their least vertical amplitude and may thus be expected to be the 'best depth' in which to work.

The theoretical investigation indicales that a single resonator would not have sufficient spread of action to fulfil the above requirements and if resonance only were to be used for reflection a number of resonators tuned to different periods would be needed as shown by Valembois [3]. This would be impracticable for a floating breakwater. Again, it has been shown earlier that if inertia only is to be employed to cause reflection, a floating breakwater of impossible size would be involved. The attack on the problem made here is to use a floating breakwater which takes advantage of both modes of reflection-reflecting the shorter waves by virtue of sheer mass and the longer waves by virtue of being shaped as a single resonator tuned to these waves.

As far as mass is concerned, the simplest way to provide mass in this case is to enclose as much water as possible within the floating breakwater. The breakwaters to be described are in effect water containers in which the mass of the enclosing structure is no more than a fraction of the total effective mass. Equation 10 provides a means of estimating the necessary mass for a given reflective effect.

The next consideration is the form of the breakwater to produce resonant reflection. Let the case of a vertical resonator (see Fig. 3) be first considered and suppose that it is desired to make the natural frequency of the internal compartment as large as practicable. Using the simple formula $\mathrm{T}=2 \pi \sqrt{(l / g)}$ for the natural period of oscillation, values obtained for the effective depth $l$ of the compartment are : 


\begin{tabular}{|c|cc|}
\hline T en secondes & \multicolumn{2}{|c|}{$I$ en pieds (mètres) } \\
\hline 6 & 29,4 & $(9)$ \\
7 & 40,0 & $(12,2)$ \\
8 & 52,3 & $(15,9)$ \\
9 & 66,1 & $(20,1)$ \\
\hline
\end{tabular}

On voit que, pour une période de 9 secondes par exemple, les dimensions verticales deviennent prohibitives. Nous avons envisagé deux facons possibles d'accroître la période propre du compartiment sans augmenter les dimensions verticales. La première consiste à disposer des chicanes inclinées à l'intérieu du compartiment, ou à utiliser un résonateur incliné (figg. 5). La

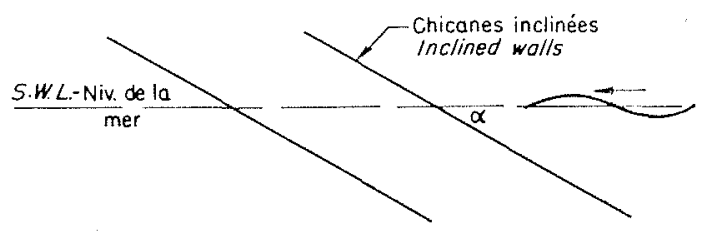

Fir. $5 a$

longueur efficace est ainsi augmentée, comme on le voit sur cette figure, en même temps que l'accélération de restitution est diminuée juscu'à $g \sin \alpha$, ce qui allonge considérablement la période propre. Ce procédé a été essayé, mais finalement abandonné, car les forces hydrodynamiques agissant sur les chicanes provoquent des mouvements horizontaux et verticaux du briselames. La seconde solution consiste à élargir le compartiment au-dessus du plan d'eau (fig. 6); on augmente ainsi la force de restitution pour un déplacement donné et, par conséquent aussi, la période, mais on rencontre de nouveau des ennuis avec les forces hydrodynamiques.

En plus de ce qui vient d'être dit, il y a lieu de rappeler que la longueur efficace est légèrement supérieure aux dimensions verticales du brise-lames, de même que la longueur efficace d'un résonateur sonique est légèrement plus grande que ses dimensions physiques. Etant donné que l'on désire utiliser le brise-lames dans des profondeurs de 30 à 40 pieds (9 à $12 \mathrm{~m}$ ), ses dimensions verticales ne devront pas dépasser les 30 pieds. Une disposition fort simple, donnée sur la figure 7 , a été choisie comme base d'étude après une série d'essais sur les modèles représentés sur les figures 5 et 6 .

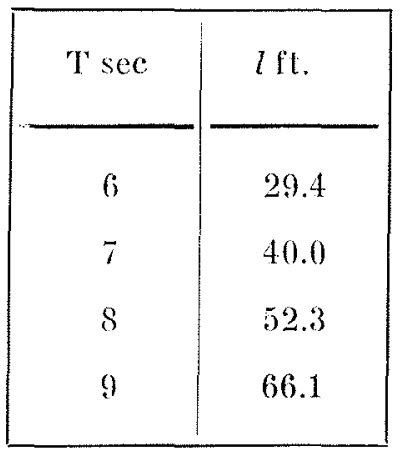

It is seen that for a period such as 9 seconds the required vertical dimension is forbidding. Two possible methods of increasing the natural period of the compartment without increasing the vertical dimension were considered. The first is the placing of inclined baffles within the compartment, or using an inclined resonator (Fig. 5). This increases the effective length as shown and

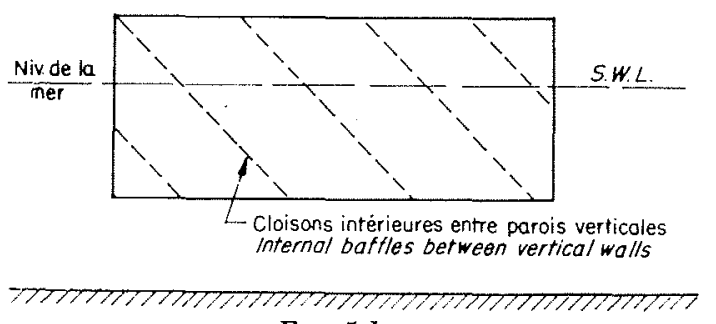

FIG. $5 b$

decreases the restoring acceleration to $g \sin \alpha$ thus greatly increasing the natural period. It was tried but finally abandoned because the hydrodynamic forces on the baffles cause horizontal and vertical movements of the breakwater, The second possibility is widening the compartment above the water line (fig. 6). This

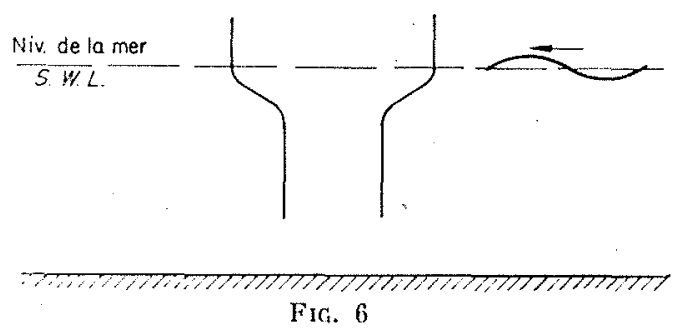

reduces the restoring force for given displacement hence increasing the period, but it, too, was found to create difficulties with hydrodynamic forces.

Apart from the above it must be remembered that the effective length is somewhat greater than the vertical dimension of the breakwater in the same way as a sonic resonator has effective length greater than its physical dimension. It is desired to use the breakwater in practice in depths of $30-40$ feet and therefore the vertical 
Dans le cas d'un résonateur horizontal, rien ne s'est opposé à ce qu'on donne au brise-lames des dimensions compatibles avec la résonance, quelle qu'en soit la période d'oscillation désirée. Si ce résonateur consiste en un simple canal ouvert aux deux extrémités (fig. 8), il devra, pour
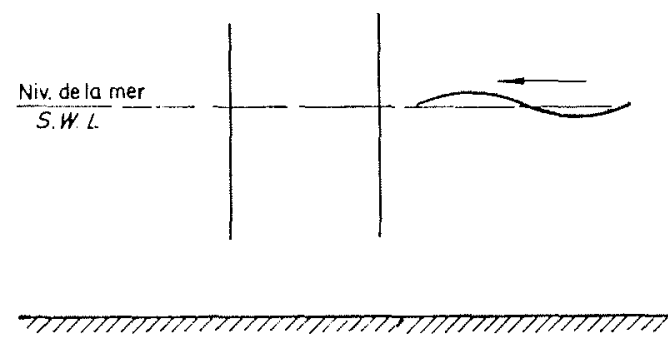

Fic. 7

être en résonance avec des ondes de différentes périodes à une profondeur d'eau de 35 pieds $(10,5 \mathrm{~m})$, avoir les longueurs suivantes :

\begin{tabular}{|c|rr|}
\hline $\mathrm{T}$ en secondes & \multicolumn{2}{|c|}{$l$ en pieds (mètres) } \\
\hline 6 & 82 & $(25,0)$ \\
7 & 102 & $(31,1)$ \\
8 & 120 & $(36,6)$ \\
9 & 139 & $(42,4)$ \\
\hline
\end{tabular}

Nous avons montré précédemment que la longueur horizontale du canal pour donner lieu à résonance est I./4. Le canal représenté sur la figure 8 étant ouvert aux deux extrémités, les longueurs ci-dessus ont été rendues équivalentes à $L / 2$. On notera que ces dimensions nécessaires sont parfaitement réalisables dans la pratique, surtout si l'on veut se rappeler que la longueur efficace d'un résonateur ouvert dépasse les dimensions du canal, comme celles du résonateur sonique. Les vraies longueurs exigées pour des périodes d'oscillation données seront donc notablement moindres que les longueurs indiquées et on en déduira que le résonateur horizontal présente sur le résonateur vertical l'avantage de se concilier avec toute période d'oscillation voulue, tandis que le résonateur vertical est pratiquement limité.

Ayant ainsi arrêté l'aspect général de l'obstacle, il y a lieu de considérer les détails d'exécution. Un corps flottant subit l'oscillation sur trois modes: pilonnement, roulis, tangage. S'il doit subir l'action de la houle, sans en être influencé, sa période propre d'oscillation dans les trois modes devra être bien plus grande que la période des vagues. dimension should be no more than 30 feet. A simple arrangement as shown in Figure 7 was therefore chosen for investigation, after exploratory tests with the types shown in Figures 5 and 6 .

Referring now to the case of a horizontal resonator, no difficulty is found in making the dimensions of the breakwater suitable for resonance to any desired wave period. If it is made a simple channel open at both ends as

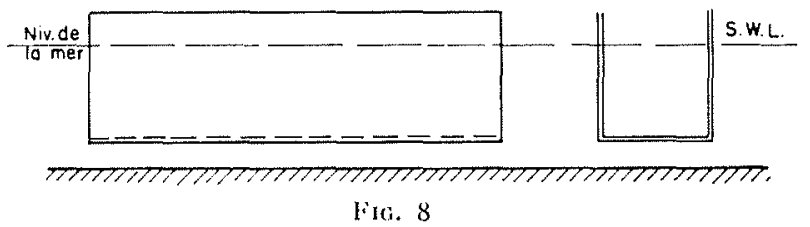

shown in Figure 8, them the required length of the channel to be in resonance with waves of various periods in a depth of 35 feet of water will be :

\begin{tabular}{|r|c|}
\hline$l \mathrm{ft}$. & $\mathrm{T} \mathrm{sec}$ \\
\hline 82 & 6 \\
102 & 7 \\
120 & 8 \\
139 & 9 \\
\hline
\end{tabular}

It was shown earlier that the required horizontal length of chanmel for resonance is $\mathrm{L}, 4$. Since the channel of Figure 8 is open at both ends the lengths given above are made equal to $\mathrm{L} / 2$. It will be seen that the dimensions required are entirely feasible in practice, especially when it is remembered that the effective length of an open resonator is greater than the dimensions of the channel, as with a sonic resonator. Thus the actual lengths required for given periods will be appreciably less than those shown. It is clear then that the horizontal resonator has the advantage over the vertical resonator in that it can be made to respond to any desired wave period, whereas there is a practical limitation on the vertical resonator.

The general shape of the barrier having been decided the detail must then be worked out. A floating body has three modes of oscillation : heaving, rolling and pitching. If it is subjected to wave action and is to be relatively unaffected by the waves, its natural period of oscillation in all three modes must be much greater than that of the waves. 
De plus, il devra posséder une certaine stabilité de flottaison pour ne pas avoir tendance à chavirer; il est donc désirable que le centre des pressions exercées par les efforts de la houle soit à un niveau aussi voisin que possible de celui du centre de gravité de l'obstacle, pour que le moment de roulis reste faible.

Ces détails ont été amplement et habilement traités par Lochner, Faber et Penney [1] et nous ne les reprendrons pas ici; nous nous bornerons simplement à faire quelques observations à propos du mouvement de pilonnement subi par les brise-lames flottants sous l'action de la houle.

Les auteurs cités ci-dessus ont fait remarquer que si l'on donnait au brise-lames flottant une petite surface de flottaison, on pourrait augmenter la période naturelle de pilonnement bien audelà des périodes de la houle; il en résulterait que, sous l'action de la houle, le brise-lames n'oscillerait plus verticalement. Mais pareil raisonnement ne tient compte que de la poussée d'Archimède seule et la déduction qu'on en tire serait juste pour des vagues relativement petites vis-à-vis des brise-lames. Si les orbites décrites par les particules d'eau dans leur mouvement sont du même ordre de grandeur que la section transversale du brise-lames et si l'on suppose que celui-ci se tient juste à la surface des eaux, les composantes verticales de la vitesse de l'eau engendreront de grandes forces hydrodynamiques sur tous les éléments horizontaux du briselames qui ne participeraient pas à ce mouvement. Il s'ensuivrait que toute forme de brise-lames, a l'exception d'un mur vertical, tendrait à osciller verticalement avec les houles de période longue.

C'est là un des ennuis que nous avons rencontrés au cours de nos expériences, expériences que nous allons maintenant exposer.

\section{Recherches expérimentales.}

Deux modèles de brise-lames flottant, concus d'après les principes ci-dessus, ont été essayés à l'échelle réduite 1: 120; le premier était un résonateur vertical, le second un résonateur horizontal.

Les expériences avaient lieu dans un canal de 25 pieds $(7,5 \mathrm{~m})$ de long, 1,5 pied $(0,45 \mathrm{~m})$ de largeur et 2 pieds $(0,60 \mathrm{~m})$ de profondeur. Pour engendrer les vagues, nous nous servions, à l'une des extrémités du canal, d'un batteur piston mis en oscillation par un mécanisme à manivelle réglable, actionné par moteur électrique avec interposition d'un variateur de vitesses. Nous obtenions de cette facon des trains de vagues d'amplitudes et de périodes extrêmement variables. La figure 9 donne une vue de l'installation. Nous avons choisi un mouvement alternatif simple du batteur pour créer les vagues, car il s'agis-
Furthermore, it must have stability of flotation so that there is no tendency to overturn and it is desirable that the centre of pressure of the wave forces be as close as possible to the same level as the centre of gravity of the barrier so that the rolling moment is kept small.

These details have been fully and ably dealt with by Lochner, Faber and Penney [1] and will not be repeated here, but it is desired to make a remark in connection with the heaving motion of floating breakwaters under wave action. In the development of this topic by the above authors it is shown that by arranging a small water-line area for the floating breakwater the natural period of heaving can be made much longer than the wave periods and hence it is assumed that the breakwater will not oscillate vertically under the wave action. 'This takes account of buoyant forces only and the conclusion will be valid while the waves are relatively small in relation to the breakwater. But when the orbits of the water motion are of the same order of size as the breakwater crosssection and the breakwater is right in the water surface, the vertical components of water velocity will produce large hydrodynamic forces on any horizontal parts of the breakwater which do not move with it. As a consequence anything but a vertical wall will tend to oscillate vertically with the longer period waves. This was one of the difficulties encountered in the experimental work now to be described.

\section{Experimental Work.}

Two designs of floating breakwater based on the foregoing principles have been tried on a model scale of 1 to 120 , one being a vertical resonator, the other a horizontal resonator.

Experimental work was carried out in a channel 25 feet long, 1.5 feet wide, 2 feet deep. Waves were generated at one end of the channel by a vertical baffle which was oscillated back and forth by an adjustable crank mechanism driven by electric motor through a variable speed drive. Waves having amplitudes and

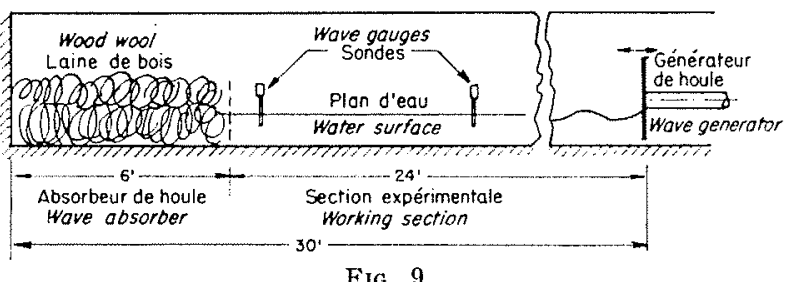

periods varying over a wide range were thus obtainable. Fig. 9 illustrates the equipment. Simple reciprocating movement of the vertical 


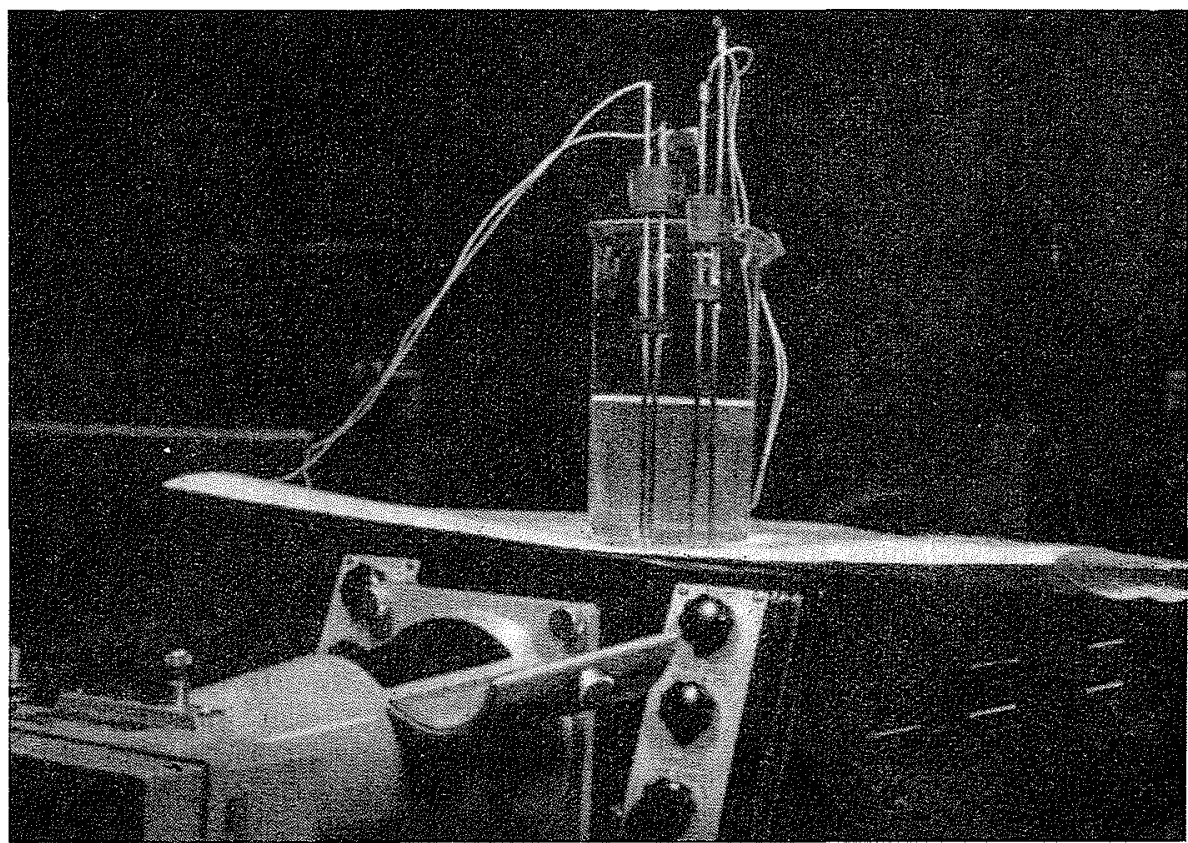

Fic. $10 a$. - Oscillographe et sondes Oscillogruph and ganges

sait d'étudier des vagues en eau peu profonde, où les composantes horizontales du mouvement de l'eau sont à peu près pareilles à toutes les profondeurs et où la longueur du canal interdisait une progression lente sur fond incliné.

A l'autre extrémité du canal, il y avait un amortisseur de vagues composé d'une cage en toile métallique remplie de fibre de bois non baffle was chosen as the means of wave generation because all the work being done is with shallow water waves in which the horizontal components of water motion are substantially the same at all depths and the length of channel does not permit of a long, sloping approach.

At the other end of the channel was placed a wave absorber consisting of a gauze basket of

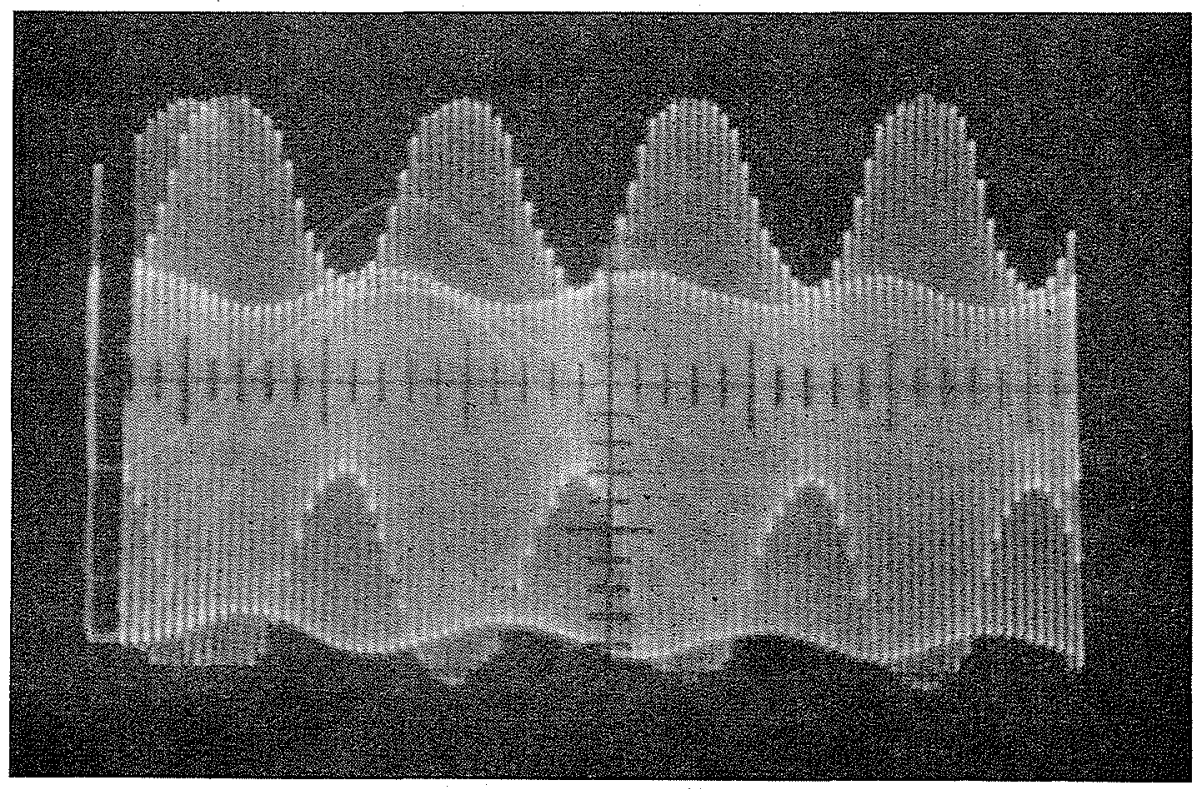

Fic. $10 \mathrm{~b}$. - Diagramme type d'oscillographe Typical oscillograph record 
tassée, qui avait la propriété de réduire la réflexion des vagues incidentes jusqu'à la rendre négligeable.

On mesurait les amplitudes au moyen de deux électrodes en laiton mises en circuit avec un oscillographe (fig. 10). Le courant alternatif à 50 périodes assurait une onde porteuse bien appropriée aux vagues produites et en mème temps constituait une base de temps utile. On étalonnait ces appareils en les plongeant à des profondeurs connues au dóbut et à la fin de chaque essai et on enregistrait les résultats à l'aide d'un appareil photographique; les mesures des amplitudes, el autres, étaient faites en dépouillant les enregistrements dans un appareil de lecture de microfilms.

La mesure des longueurs était obtenue à l'aide de deux index distants entre eux d'une longueur réglable et réunis en circuit avec deux lampes au néon qui produisaient un éclat lumineux à chaque contact avec l'élément liquide. Les index étaient réglés de manière que leurs éclats lumineux soient symchronisés avec chaque passage de vague, car alors leur écartement forme un multiple entier de la longueur d'onde. Les mouvements effectués par les obstacles flottants sous laction des vagues étaient mesurés à la main avec une règle graduée.

L'appareil ayant été essayé et étalonné, il a été procédé à l'essai du système d'amarrage sur les modèles servant aux essais, comme on le voit sur la figure 11. Nous avons dit qu'en pratique le système d'amarrage d'un brise-lames flottant pouvait ètre considéré comme un ressort et que pour toutes les valeurs pratiquement possibles de la raideur du « ressort », la grandeur de cette raideur est d'un effet négligeable sur le mourement du brise-lames. Dans notre essai nous avons utilisé des raideurs différentes et les résultats obtenus, présentés sur les graphiques, viennent à l'appui de l'hypothèse initiale.

Nous avons exécuté un certain nombre d'essais préliminaires à titre d'exploration sur différents modèles de brise-lames, comme ceux représentés sur les figures 6 et 7 . Nous avons rencontré constamment la difficulté déjà mentionnée, provenant du mouvement de pilonnement du briselames accompagnant la houle et supprimant ainsi toutes les raisons de résonance, c'est-à-dire réduisant l'efficacité de l'ouvrage.

En résumé, ces essais préliminaires ont établi que tous les brise-lames, même ceux à simples parois verticales, oscillent verticalement avec la houle dans une certaine mesure et qu'il s'agit de réduire ce mouvement suffisamment si l'on veut obtenir une bonne résonance dans le briselames. Ils ont montré aussi qu'avec des briselames de ce genre, des surfaces de flottaison trop petites donnent de l'instabilité vis-à-vis de l'action du roulis. lightly packed wood wool. This was found to reduce reflection of any entering wave to a neglisible degree.

Wave amplitudes were measured by wave gauges comprising two brass electrodes connected in an electrical circuit with an oscillograph (Fig. 10). The 50-cycle a.c. supply provided a very convenient carrier wave for the water waves and at the same time served as a useful time base. The wave gauges were calibrated by immersion at known depths at the beginning and end of each experimental rum. Results were recorded photographically by means of a recording camera, and measurements of amplitudes etc. were made from the film records using a microfilm reader.

Wave lengths were measured by two pointers whose distance apart is adjustable, connected in circuit with two neon lamps which flash each time the pointer makes contact with the water. The pointers are adjusted so that their flashes synchronise when waves are passing and their distance apart is then a whole number of wave lengths. Movements of floating barriers under wave action were measured with a rule by hand.

When the apparatus had been tested and calibrated a test was made of the system of restraining the models adopted for the tests, shown in Figure 11. It has been indicated that in
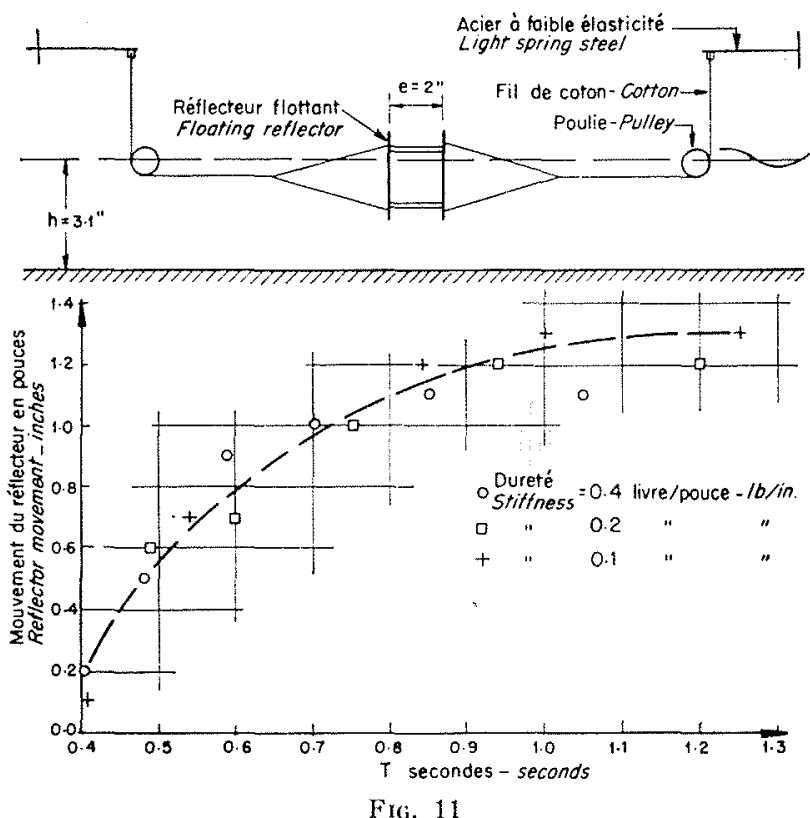

practice the mooring system of a floating breakwater may be considered as a spring, and that for all practically possible stiffnesses of the 'spring' the magnitude of the stiffness has negligible effect on the motion of the breakwater. In this test varying spring stiffnesses were used, and the results, shown graphed, verify the original hypothesis. 
Nous avons alors tourne notre attention vers un brise-lames du modèle qu'on voit sur la figure $12 a$, représentant le dernier mot de la simplicité. On pouvait penser qu'il aurait la même période propre d'oscillation verticale que la colonne d'eau qu'il renfermait et qu'ayant une bonne flottabilité et la liberté de mouvements verticaux, il supprimerait vraisemblablement toute cause de mouvement en résonance de la colonne d'eau. Cependant, on a préféré construire le modèle et l'essayer, car on avait observé au cours des essais préliminaires que, dans

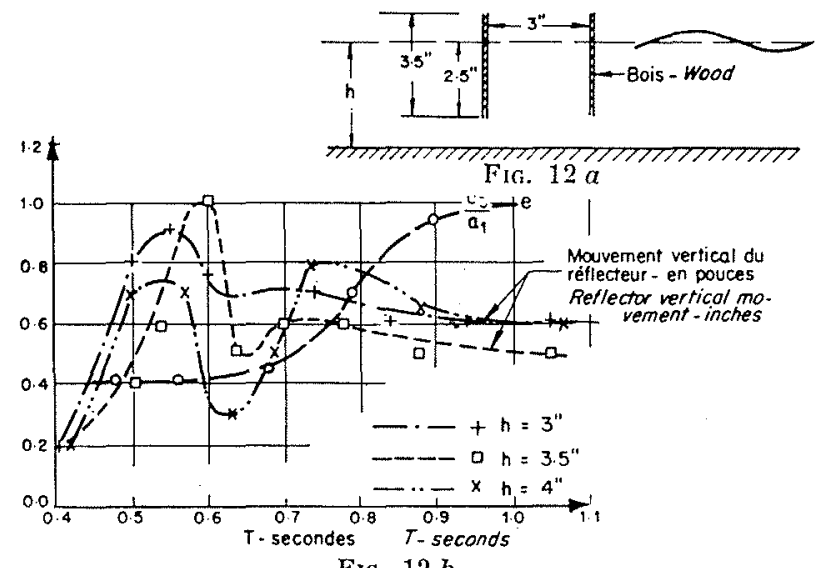

Fig. $12 b$

ces conditions, la résonance subsiste. Comme toujours en pareil cas, les mesures furent précédées d'un certain nombre d'observations qua-
A number of preliminary and exploratory tests were made on different designs of breakwater of the kinds shown in Figures 6 and 7 . The difficulty found with all of these was the one already mentioned, namely the heaving motion of the breakwater with the waves, thus removing all cause for resonance and hence reducing the effectiveness of the breakwater.

Summarised, the results of these preliminary tests were that all breakwaters, even those with simple vertical sides, heave up and down with the waves to some extent and it is a question of reducing this motion sufficiently to obtain useful resonance in the breakwater. It was also found that with breakwaters of the kind envisaged, excessively small water line areas led to lack of stability in relation to rolling action. A breakwater of the design shown in Figure $12 a$ was then considered, this being the ultimate in simplicity. It was realised that this would have a natural period of vertical oscillation the same as that of the water column within it, and because of its buoyancy and vertical movements any cause for resonant motion of the water column would apparently be absent. However, the design was built and tried because of the observation in the preliminary tests that resonance did occur under such conditions. As in the other cases, a number of qualitative observations were made before measurements were commenced.
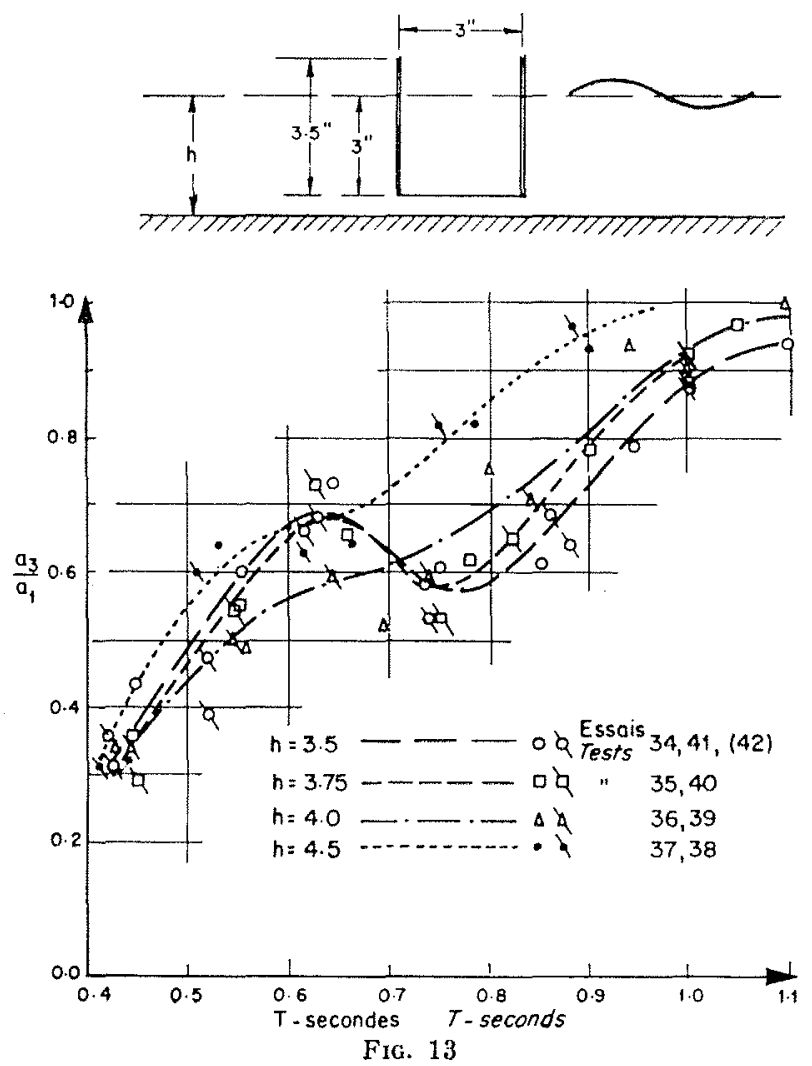
litatives. Une constatation importante a été qu'un obstacle de ces dimensions ne devrait pas ètre utilisé dans des eaux ayant moins de 3,5 pouces $(9 \mathrm{~cm})$ de profondeur dans le bassin, c'est-à-dire 35 pieds $(10,5 \mathrm{~m})$ d'eau dans la réalité; autrement il resterait trop peu de place au-dessous pour donner lieu au mouvement de résonance; d'autre part, l'obstacle pourrait heurter le fond. On procéda alors à un essai de détail $\left(n^{\circ} 33\right)$ dont les résultats sont résumés sur la figure $12 \mathrm{~b}$.

Nous avons ensuite examiné le résonateur horizontal (fig. 13) auquel nous avons donné la même profondeur et la même épaisseur qu'au résonateur vertical; sa longueur seulement était moitié de celle de l'onde pour laquelle on cherchait à obtenir la résonance. Dans le cas présent, elle était de 13 pouces $(33 \mathrm{~cm})$, correspondant à une période d'environ $0,8 \mathrm{~s}$ (9 $\mathrm{s}$ sur le prototype), compte tenu de la «longueur efficace » supplémentaire. Il restait donc une longueur disponible de $21 / 2$ pouces $(6,4 \mathrm{~cm})$ à chaque extrémité du canal à houle, pour. l'entrée et la sortie de l'eau. Du fait que le résonateur est fermé, tout mouvement de pilonnement ou de roulis de la barrière est très fortement amorti et les divers inconvénients des modèles antérieurs éliminés, à condition. que la profondeur sous le fond $\mathrm{du}$ brise-lames ne soit pas excessive. Ces essais, nnmérotés 34 à 42 , ont été effectués dans les conditions suivantes:

\begin{tabular}{|c|cc|cc|}
\hline $\begin{array}{c}\text { Essai } \\
N^{\circ}\end{array}$ & \multicolumn{2}{|c|}{$\begin{array}{c}\text { Profondeur de l'eau } \\
\text { en pouces }\end{array}$} & \multicolumn{2}{|c|}{$\begin{array}{c}\text { Amplitude de la vague } \\
\text { en pouces }\end{array}$} \\
\cline { 2 - 3 } 34 & 3.35 & 8.5 & 0,6 & 1,5 \\
35 & 3,75 & 9,5 & 0,6 & 1,5 \\
36 & 4,00 & 10,2 & 0,6 & 1,5 \\
37 & 4,50 & 11,4 & 0,6 & 1,5 \\
38 & 4,50 & 11,4 & 1,0 & 2,5 \\
39 & 4,00 & 10,2 & 1,0 & 2,5 \\
40 & 3,75 & 9,5 & 1,0 & 2,5 \\
41 & 3,50 & 8,8 & 1,0 & 2,5 \\
42 & 3,35 & 8,5 & 1,0 & 2,5 \\
\hline
\end{tabular}

La variation de profondeur de l'eau correspond à un marnage de 11.5 pieds $(3.45 \mathrm{~m})$. Les résultats de nos essais 34 à 42 sont réunis sur la figure 13; la figure 14 donne une vue du phénomène. A noter que chaque fois que, dans les essais de cette série, apparaissait une forte réso-
One important conclusion thus reached was that the barrier with these dimensions should not be used in a water depth of less than 3.5 inches, (i.e. $35 \mathrm{ft}$. prototype) since otherwise there is insufficient space underneath for the resonant flow to occur and also the barrier is liable to hit bottom. The model was then tested in detail (test No. 33.) and the results are shown in $\mathrm{Fi}$ gure $12 b$.

The horizontal resonator (see Fig. 13) was next investigated. The depth and thickness were made the same as the vertical resonator but the length was made equal to half the length of the wave for which resonance was desired. In this case the length was made 13 inches corresponding to a period of about 0.8 seconds (about 9 seconds prototype) when allowance is made for the extra 'effective length'. This left a space of $2 \frac{1}{2}$ inches within the wave flume clear at each end for the inflow and outflow of water. The closed-in bottom of the resonator means that any heaving or rolling movement of the barrier is very heavily damped and the difficulties of the previous types are avoided provided the bottom clearance is not excessive. The tests on this model were numbered 34 to 42 the quantities varied being as follows :

\begin{tabular}{|c|c|c|}
\hline $\begin{array}{c}\text { Test } \\
\text { No }\end{array}$ & $\begin{array}{c}\text { Water depth } \\
\text { inehes }\end{array}$ & $\begin{array}{c}\text { Wave amplitude } \\
\text { inches }\end{array}$ \\
\hline 34 & 3.35 & 0.6 \\
35 & 3.75 & 0.6 \\
36 & 4.00 & 0.6 \\
37 & 4.50 & 0.6 \\
38 & 4.50 & 1.0 \\
39 & 4.00 & 1.0 \\
40 & 3.75 & 1.0 \\
41 & 3.50 & 1.0 \\
42 & 3.35 & 1.0 \\
\hline
\end{tabular}

The variation in water depth corresponds to a tidal range of 11.5 feet. The results of tests 34 to 42 are plotted together in Figure 13, a picture of the action being seen in Figure 14. It should be mentioned that in all tests of this series when strong resonance occurred, the amplitude of the 


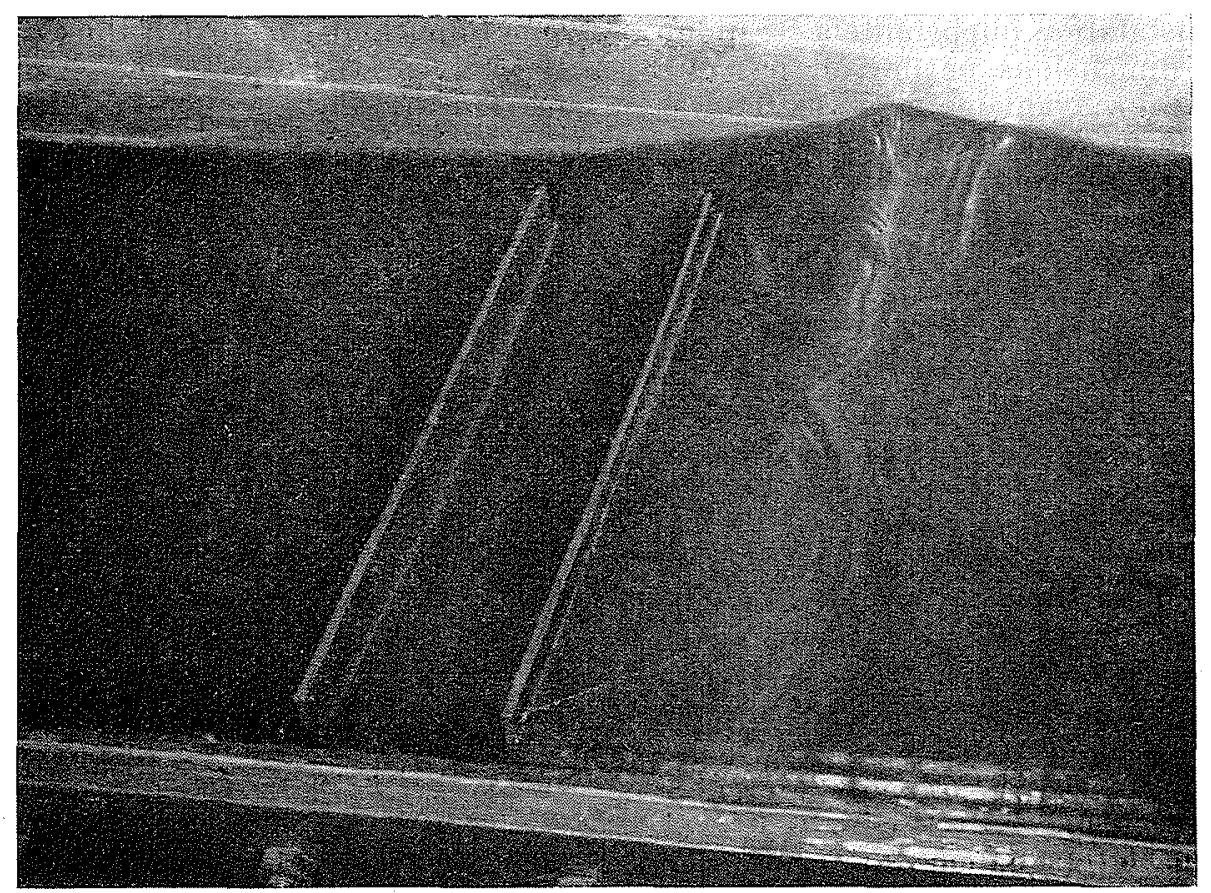

nance, l'amplitude de l'onde de résonance élait telle que l'eau débordait sur les côtes du briselames.

\section{Discussion des résultats d'expérience.}

Le problème de l'oscillation verticale, ou pilon- resonant wave was such that it overllowed the sides of the breakwater.

\section{Discussion of experimental results.}

The problem of vertical oscillation or heaving of the model breakwaters under wave action

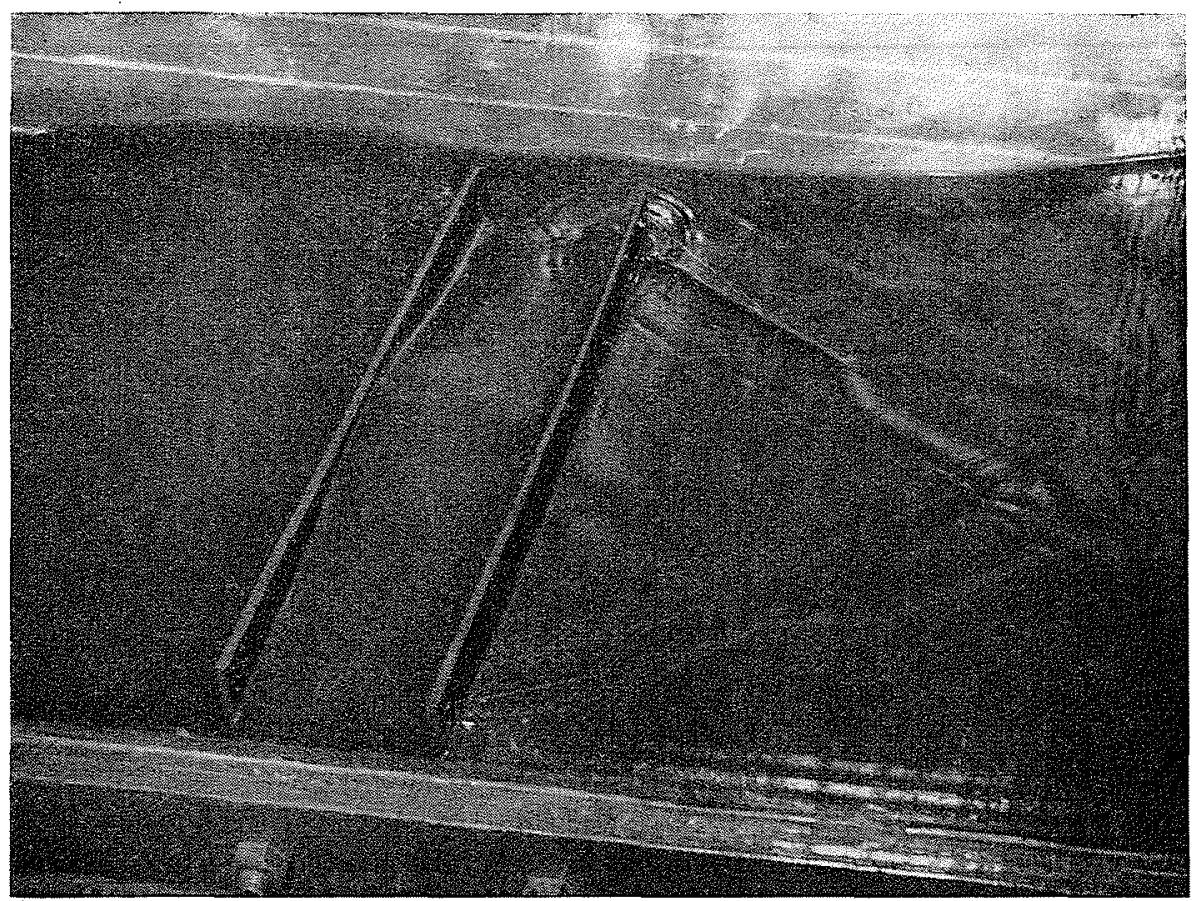

Fri. 14 a. - Résonateur horizontal en fonctionnement. Onde incidente venant de la droite The horizontal resonator in action. Incident wave coming from right 


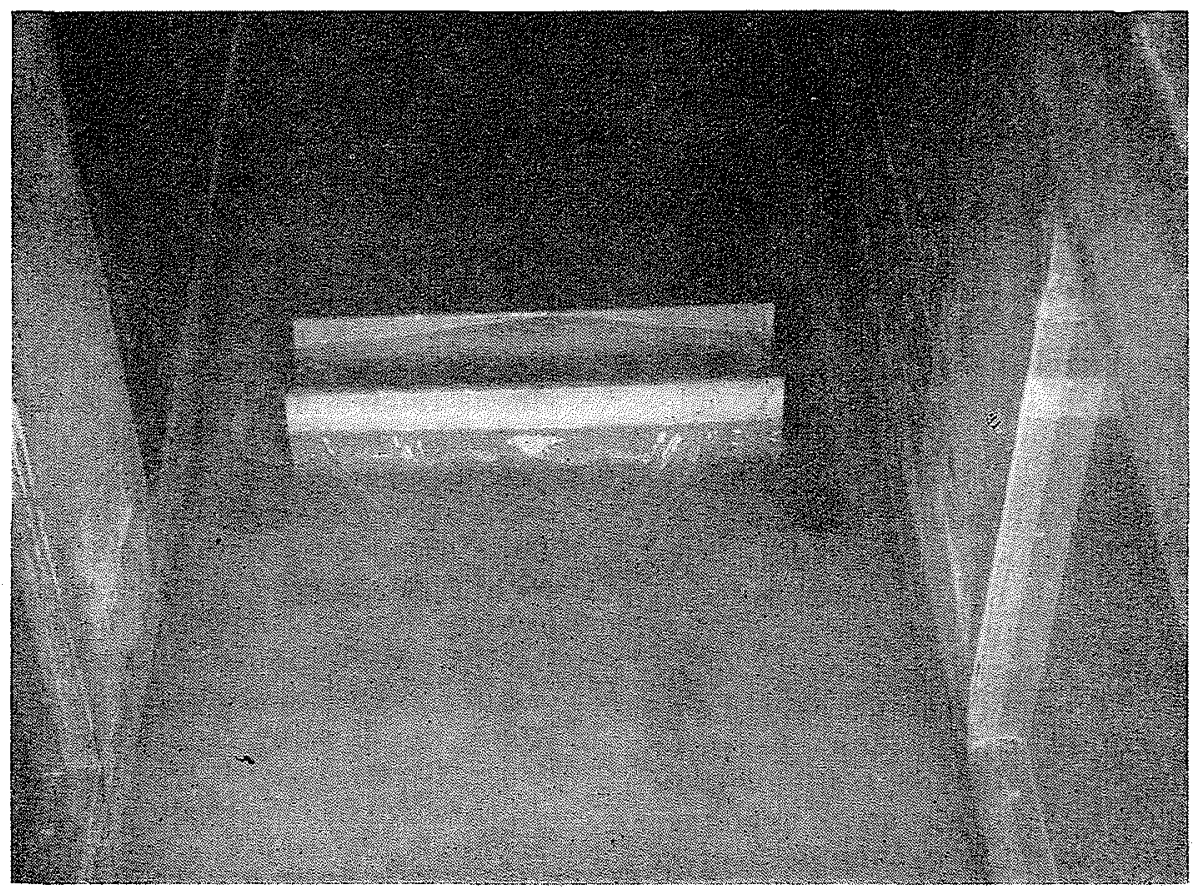

nement, des modèles de brise-lames, causé par la houle, n'a pas cessé de'se manifester lors de ces expériences. On doit reconnaitre que le caractère $d u$ « rocher flottant » attribué aux corps ayant une longue période d'oscillation n'a pas été apprécié, car les efforts dynamiques l'emportent sur la poussée d'Archimède. Les brise- recurred continually during the experimental work. It must be said that the 'floating rock' character, ascribed to bodies of long natural periods, has not been realised, because dynamic forces overshadow buoyant forces. Every breakwater tested 'rode the waves' in varying degree. When a breakwater having vertical sides and

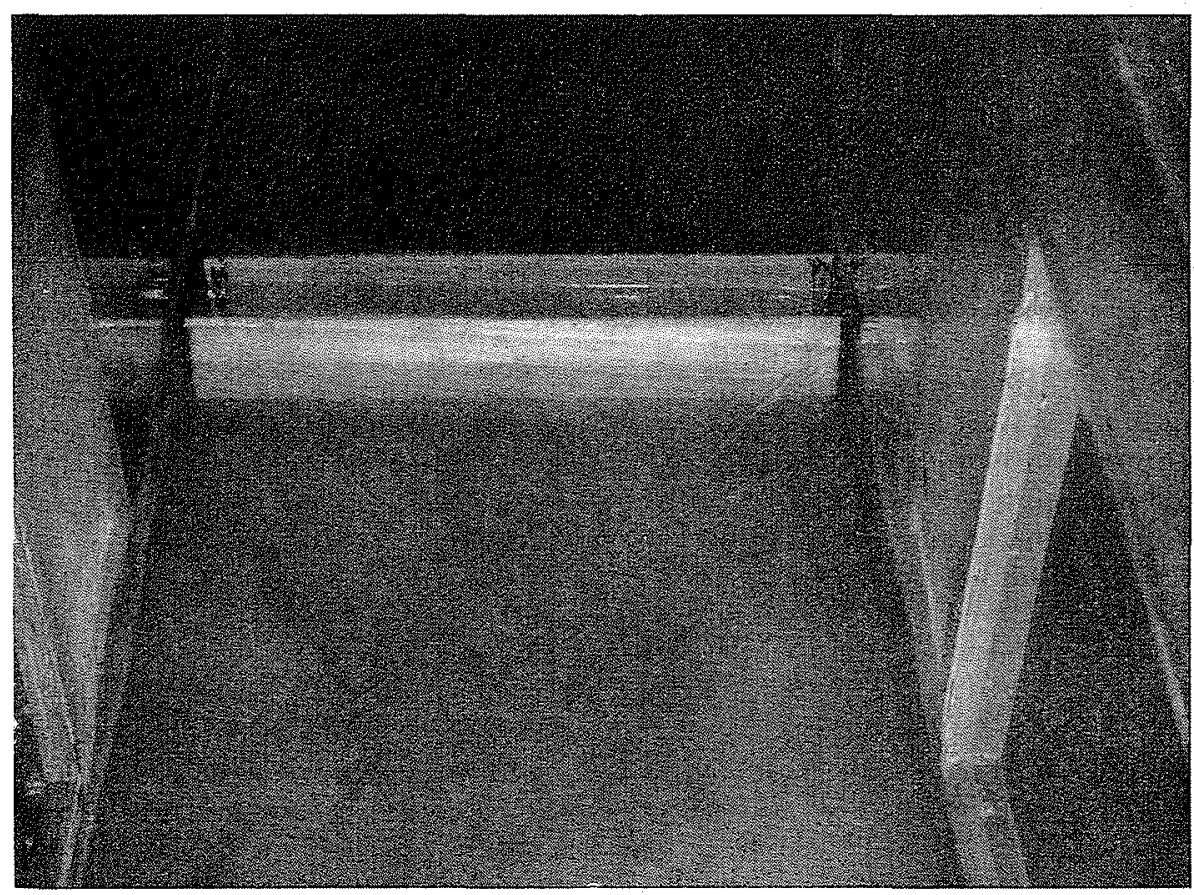

Fig. $14 b$. -... Résonateur horizontal Horizontal resonator 
lames essayés ont tous « chevauché les vagues», bien qu'à un degré différent. Un brise-lames à parois verticales ayant une longue période propre avait de ce fait un mouvement de roulis fort lent; il prenait de la gîte sous l'action des vagues, provoquant ainsi l'apparition des forces hydrodynamiques et le mouvement vertical qui s'ensuivait. Nous avons done dû abandonner notre tentative d'empêcher toute oscillation verticale du brise-lames et recourir au modele simple représenté sur la figure $12 a$. Les résultats obtenus furent très intéressants (fig. $12 b$ ).

Aux houles de période courte, l'obstacle est assez rigide; avec l'allongement de la période, l'oscillation verticale augmente, puis baisse brusquement à l'approche de la période propre et enfin augmente de nouveau avec les vagues de période plus longue. Cette action incite fortement à penser que l'eau emprisonnée dans l'obstacle joue pour celui-ci le rôle d'un absorbeur de vibrations amorties, Ieffet de frottement de ses propres oscillations neutralisant sa tendance à l'oscillation. Donc, là où l'on cherche à créer un rocher flottant, on l'obtient mieux avec ce genre d'obstacle qu'avec tout autre « correctement calculé $\gg$; corrélativement, la réflexion par résonance est aussi meilleure. Pour toutes les périodes autres que la période propre il y a un mouvement vertical considérable, mais pas assez prononcé pour être nuisible, puisque tout système d'amarrage doit offrir une marge d'élasticité pour tenir compte des marées aussi bien que de la houle. On peut donc affirmer que, d'après les résultats de cet essai $\left(n^{\circ} 39\right)$, un obstacle flottant en résonance verticale oppose une action réfléchissante à toutes les houles jusqu'à la période $0,7 \mathrm{~s}$ sur le modèle, c'est-à-dire environ $8 \mathrm{~s}$ dans la nature.

Dans le cas du résonateur horizontal (essais 34 à 42), le mouvement vertical crée des difficultés moins ardues; il se produit quand même, comme on le déduit des résultats des essais, mais l'amortissement est si fort que l'amplitude de ce mouvement parasite n'excédera jamais celle de la houle. Néanmoins, il faut chercher à le réduire à un minimum, puisque la résonance de l'eau ne peut être due qu'à des changements du niveau de l'eau par rapport au brise-lames; si celui-ci monte et descend avec la vague, il ne peut y avoir de déplacement relatif. L'examen de ces résultats vient également le confirmer; en effet, on voit que là où le déplacement vertical est le plus grand, la réflexion par résonance est la plus faible. On notera également que plus grande est la profondeur sous le fond du briselames, plus marqué est le mouvement en hauteur. La raison de ce phénomène est probablement la répartition des pressions, puisque en dernière analyse ce sont les variations de pression qui provoquent le mouvement. Quand l'in- very long natural period was built its rolling action was (consequently) very sluggish. This caused the breakwater to list under wave action, thus bringing vertical hydrodynamic forces into play and causing vertical movement. This led to the abandonment of the attempt to prevent all vertical oscillation of the breakwater and the use of the simple design shown in Figure $12 a$. The results (Fig. $12 b$ ) are very interesting. For the short period waves, the barrier is fairly steady; as the period increases the vertical movement increases, then decreases sharply near the natural period, after which it increases again with the longer period waves. The action strongly suggests that the water within the barrier acts as a damped vibration absorber for the barrier, the frictional effect of its own oscillations neutralising the tendency of the barrier to oscillate. Thus in the region where the 'floating rock' is needed, it is realised more effectively with this barrier than with any of the 'correctly' designed barriers, and the resonant reflection is correspondingly better. At all periods other than the natural cne, the vertical movement is considerable, but not so great as to be harmful, since every mooring system must have a margin of flexibility to allow for tides as well as waves. It can be stated therefore that the results of this test (numbered 33) show that a vertically resonant floating barrier has a uscful reflective action on all waves up to a period of 0.7 seconds on the model, which corresponds to about 8 seconds in nature.

In the case of the horizontal resonator (tests 34 to 42 ) the difficulties with vertical movement are not so acute. It still occurs, as may be seen in the test results, but the damping is so heavy that its amplitude can never exceed that of the waves. Nevertheless, it is desirable to keep it to a minimum since water resonance can result only from changes of level relative to the breakwater and if it moves up and down with the wave there is no change of relative water level. Examination of the test results confirms this, for it may be seen that where vertical movement is greatest, resonant reflection is least. Also it may be noticed that the greater the bottom clearance of the breakwater, the greater is the vertical movement. The reason for this probably is related to pressure distribution, since in the last analysis it is changes of pressure that cause the movement. When the bottom clearance is large, the pressure under the breakwater is close to simple hydrostatic as the wave passes, with corresponding large upward force. When the bottom clearance is small, water is rushing through underneath the breakwater as the wave passes, giving a Bernoulli effect and a reduction in pressure. The inference is that it is desirable to operate this type of breakwater with the 
tervalle sous le fond est grand, la pression s'exercant sous le brise-lames se rapproche beaucoup de la pression hydrostatique pure et simple au moment du passage de la lame; il y a donc une grande force de soulèvement. Quand, au contraire, l'intervalle est faible, l'eau se précipite sous le brise-lames, au passage de la lame, déterminant un effet Bernoulli et une baisse de pression. On en déduit qu'il convient d'utiliser les brise-lames de ce genre avec le minimum possible de passage sous leur fond. On pourra alors allonger à volonté la période propre de résonance sans difficulté. Le modèle essayé avait une longueur qui correspondrait à 130 pieds $(40 \mathrm{~m})$ en vraie grandeur, ce qui n'aurait certainement pas causé d'ennuis, puisque le Bombardon avait 200 pieds $(60 \mathrm{~m})$; sa période naturelle serait d'environ $9 \mathrm{~s}$ à l'échelle réelle. Les mêmes résultats des essais prouvent qu'avec ce brise-lames on obtient une réflexion utile avec des vagues de toutes périodes jusqu'à envirion 10 sécondes.

Il est intéressant de comparer l'efficacité du résonateur vertical à celle du résonateur horizontal, en ne perdant pas de vue que le résonateur vertical a à peu près $17.5 \mathrm{in} .(46 \mathrm{~cm}) \mathrm{de}$ longueur et barre ainsi la presque totalité de la largeur du canal, tandis que le résonateur horizontal n'a que 13 pouces $(34 \mathrm{~cm})$ de longueur et laisse un intervalle de $21 / 2$ pouces $(6,6 \mathrm{~cm})$ à chaque bout. Une façon aisée de tenir compte de cette différence est de mettre les résultats sous forme non dimensionnelle, en portant les valeurs $d u$ coefficient de transmission en fonction du paramètre $m g / w h \mathrm{~L}$. C'est ce qu'on voit sur la figure $15 a$, où la courbe théorique déduite de l'équation (10) a été également tracée à titre de référence. Les courbes expérimentales correspondent aux conditions optima, aussi bien pour le résonateur vertical (essai 33 ) que pour le résonateur horizontal (esai 41). On y reconnait facilement les effets de la résonance.

Deux circonstances peuvent expliquer le fait que la courbe expérimentale passe en dessous de la courbe théorique. D'abord la courbe théorique a été trouvée en supposant que l'obstacle s'étend sur toute la profondeur de l'eau, tandis que les brise-lames réels n'en occupent qu'une partie. Cela semblerait indiquer qu'une masse donnée a une plus grande action quand elle est concentrée à la partie supérieure de l'eau que si elle est dispersée sur toute sa profondeur. Ensuite, la masse virtuelle de l'obstacle a dû être notablement sous-estimée, car on n'a certainement pas tenu compte de la masse de l'eau extérieure entraîné avec l'obstacle. On est donc en droit de supposer que le diagramme sans dimensions n'est pas ce qu'il y a de plus réel comme base de comparaison. C'est pourquoi nous avons tracé le diagramme de la figure $15 a$, sur lequel les coefficients de transmission obtenus sont portés minimum bottom clearance practicable. With this design there is no difficulty in making the natural period of resonance as long as desired. The model tested has a corresponding length in practice of 130 feet which would not cause any difficulty (the Bombardon was 200 feet long) and its natural period is about 9 seconds in nature. The test results show that useful reflection occurs with this breakwater for waves of all periods up to about 10 seconds.

It is interesting to compare the performance of the vertical and the horizontal resonators. In doing this it must be borne in mind that the vertical resonator is $17 \%$ inches long, almost completely spanning the width of the channel, whereas the horizontal resonator is 13 inches long, leaving a gap of $2 \%$ inches at each end. One simple way of allowing for this is to put the results in dimensionless form by plotting the transmission coefficient against the parameter $(\mathrm{mg} / \mathrm{whL})$. This is shown in Figure $15 \mathrm{a}$ with the theoretical curve of equation 10 reproduced for reference. The experimental curves refer to the vertical resonator under optimum conditions (test 33) and the horizontal resonator under optimum conditions (test 41). The effects of resonance are clearly seen.

The fact that the experimental curve falls below the theoretical curve is probably explained by two facts. First, the theoretical curve is derived on the assumption that the barrier extends through the full water depth, whereas the actual breakwater's occupy only part of the depth. This may indicate that a given mass is more effective when concentrated in the upper part of the water than when spread through the full depth. Secondly, the virtual mass of the barrier has no doubt been considerably underestimated, no allowance having been made for any water outside the barrier being carried with it. This suggests that the dimensionless plot is not the most realistic basis of comparison, and for this reason the alternative plot of Figure $15 b$ was produced, showing the transmission coefficients to be expected plotted against wave period for model and prototype. In preparing this, allowance was made for the difference in length between the vertical and the horizontal resonator, as follows. In practice vertical resonators could not be moored touching end to end any more than horizontal ones could. The Bombardons were moored with $20 \%$ spacing between them and this basis is adopted for the vertical resonators. Treating the matter on an energy basis, let $\mathrm{E}$ be the energy in the incident wave, then $0.2 \mathrm{E}$ passes the barriers untouched. Of the remaining $0.8 \mathrm{E}$ the amount passing the barrier is $0.8\left(a_{3} / a_{1}\right)^{2} \mathrm{E}$ since energy is proportional to the square of the amplitude, making the total 
en fonction de la période de la houle du modèle et $d u$ prototype. Nous y avons tenu compte de la différence de longueur entre le résonateur vertical et le résonateur horizontal de la facon suivante :

En pratique, les résonateurs verticaux ne pourraient être amarrés bout à bout, pas plus que les résonateurs horizontaux. Les Bombardons étaient amarrés avec un intervalle de $20 \%$ qui a été également adopté pour les résonateurs verticaux. En considérant la question du point de vue des énergies, si $\mathrm{E}$ représente l'énergie de la vague incidente, la fraction $0,2 \mathrm{E}$ passe sans toucher aux obstacles. De la fraction $0,8 \mathrm{E}$ restante, l'énergie traversant l'obstacle est $0,8\left(a_{3} / a_{1}\right)^{2} \mathrm{E}$, car elle est proportionnelle au carré de l'amplitude; l'énergie totale de la masse ayant traversé est done $0,2 \mathrm{E}+0,8 \mathrm{E}\left(a_{3} / a_{1}\right)^{2}$. Soit $a_{4}$ l'amplitude corrigée de l'onde transmise; on pourra écrire :

$$
\begin{gathered}
\frac{\text { énergie transmise }}{\text { énergie incidente }} \\
=\left(a_{4} / a_{1}\right)^{2}=\frac{0,2 \mathrm{E}+0,8 \mathrm{E}\left(a_{3} / a_{1}\right)^{2}}{\mathrm{E}}
\end{gathered}
$$

le coefficient de transmission corrigé serait done:

$$
a_{4} / a_{1}=\sqrt{0, \dot{2}+0,8\left(a_{3} / a_{1}\right)^{2}}
$$

Ces coefficients corrigés ont servi de base à l'établissement de la figure $15 \mathrm{~b}$ en ce qui concerne le résonateur vertical. On n'a pas eu à corriger les coefficients relatifs au résonateur horizontal, car, déjà aux essais, il comportait un espacement de $38 \%$ et est toujours désavantagé en comparaison du résonateur vertical. La figure $15 b$ rend clairs les effets de la résonance et la période propre plus longue du résonateur horizontal.

D'autres points de comparaison des deux types de résonateur se déduisent de l'étude des résultats donnés sur les figures 12 et 13 . L'un de ces points est que le résonateur vertical est assujetti à des oscillations verticales plus fortes que l'horizontal; il est donc moins « docile ». Un autre point est que le résonateur horizontal perd beaucoup de ses effets de résonance s'il présente un grand espace libre en dessous du fond, comme pendant l'essai 37 . Encore un autre point de comparaison est que la cambrure $a_{1} / \mathrm{L}$ du front de la vague n'a pas d'effet sensible sur le coefficient de transmission.

Les modèles n'ont pas un franc-bord très important; aussi dans le cas de la résonance, la vague intérieure débordait souvent l'obstacle et parfois des vagues incidentes de forte amplitude franchissaient la face amont. Cependant la quantité d'eau qui déborde n'a jamais été bien grande et en tous les cas elle représente une dissipation d'énergie que l'obstacle doit produire d'une fa- energy passing equal to $0.2 \mathrm{E}+0.8 \mathrm{E}\left(a_{3} / a_{1}\right)^{2}$. Let $a_{4}$ be the adjusted amplitude of the transmitted wave; then :

$$
\begin{gathered}
\frac{\text { Transmitted energy }}{\text { Incident energy }} \\
=\left(a_{4} / a_{1}\right)^{2}=\frac{0.2 \mathrm{E}+0.8 \mathrm{E}\left(a_{3} / a_{1}\right)^{2}}{\mathrm{E}}
\end{gathered}
$$

so that the adjusted transmission coefficient :

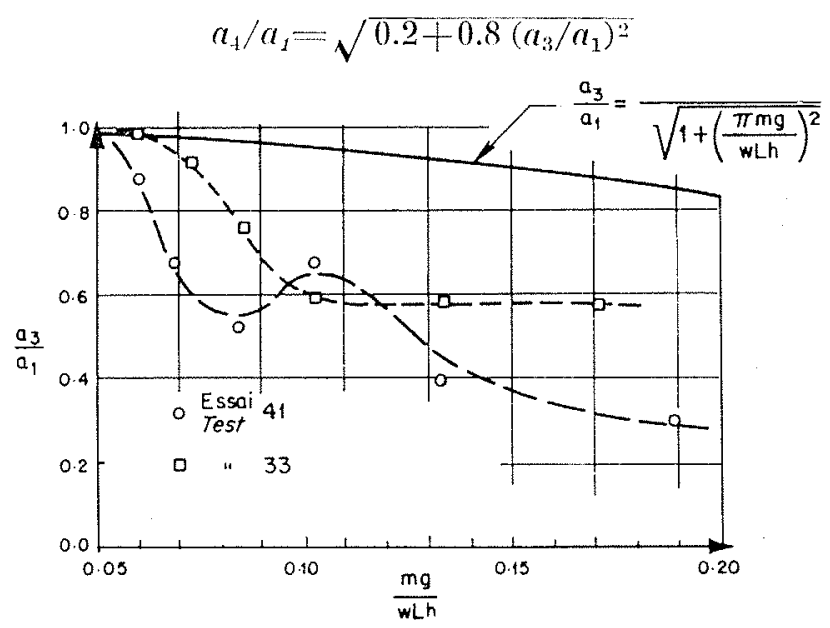

FIG. $15 a$

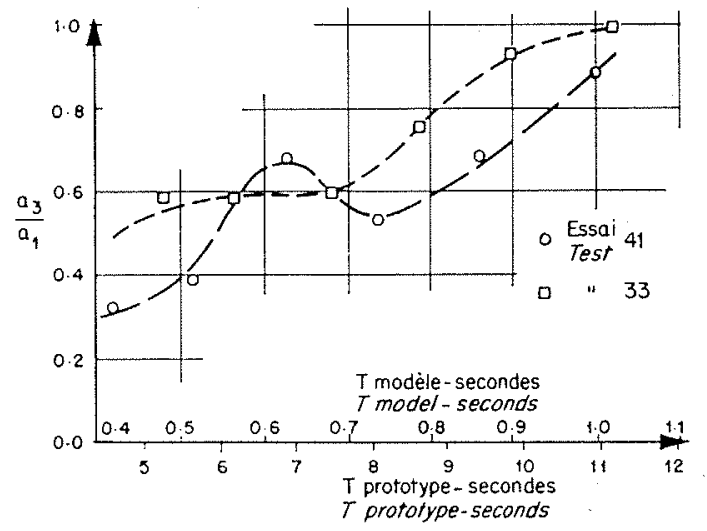

Fic. $15 b$

These adjusted transmission coefficients were then used in Figure $15 \mathrm{~b}$ for the vertical resonator. No adjustement was made to the horizontal resonator coefficients since in the test it already had a $38 \%$ spacing and is still at a disadvantage compared to the vertical. Figure $15 \mathrm{~b}$ shows clearly the effects of resonance, and the longer natural period of the horizontal resonator.

Other points in the comparison of the two types of resonator emerge from a study of the results in Figures 12 and 13. One is that the vertical resonator is subject to greater vertical oscillation than the horizontal and is therefore less 'docile'. Another is that the horizontal resonator loses most of its resonant effect if it 
con ou d'une autre. Le franc-bord a été limité intentionnellement pour répondre aux conditions de la réalité, car sur le prototype on limitera nécessairement les dimensions pour réduire d'une part les frais, d'autre part l'effort du vent.

Enfin, il y a lieu d'ajouter quelques mots sur l'effet d'échelle, éventuel, qui pourrait affecter les valeurs obtenues sur le modèle. Cet effet n'a que deux causes dans le cas étudié : la tension superficielle et la viscosité. On pourra négliger la première, mais la viscosité pourrait exercer son action sur les mouvements de l'eau en résonance. L'effet amortisseur de la viscosité serait plus accentué sur le modèle que sur le prototype, car le nombre de Reynolds est bien plus petit pour le premier. On en déduira qu'au point de vue résonance, les prototypes seront légèrement plus avantageux que ne le laisseraient préyoir les modèles. Le travail que nous avons exécuté se rapportait à un prototype cent vingt fois plus grand que le modile, mais il va de soi que les valeurs obtenues peuvent être transposées à une autre échelle quelconque à l'aide des méthodes de similitude connues.

\section{CONCLUSION}

La conclusion principale à tirer de ces recherches est que l'inertie et la résonance, combinées dans un résonateur vertical, réfléchissent au moins $50 \%$ de l'énergie des vagues de toute période jusqu'à 8 secondes et, dans un résonateur horizontal, jusqu'à 10 secondes. Il y a lieu de supposer que ce taux de réflexion suffit à la protection des plages à peu près en tous les cas et qu'il serait aussi utilisable dans maintes autres applications. Le résonateur horizontal serait préférable pour la protection des plages, car il a un rayon d'action plus grand et pilonne moins pendant son action.

Les avantages que présente un réflecteur de vagues, ou brise-lames flottant, sont tout a fait évidents. C'est un élément mobile, ne dépendant pas de la marée; tout en protégeant la plage, il offre maintes autres possibilités d'application utile : protection d'onvrages provisoires, de ports saisonniers, protection supplémentaire s'ajoutant à la protection usuelle des ports permaments. Dans le cas des ports, le coût de son installation ne sera qu'une fraction de celui des brise-lames permanents classiques.

D'autre part, il nous faut aussi indiquer les raisons limitant l'emploi du procédé. Le dispositif a peu d'action sur des vagues dépassant sensiblement les périodes de 10 secondes et ne pourrait pas être utilisé sur n'importe quelle côte hattue par des vagues d'extrême violence. Le résonateur horizontal perd la plus grande partie has a large bottom clearance as in test 37 . Still another is that wave steepness $a_{1} / \mathrm{L}$ has no appreciable effect on transmission coefficient.

The amount of freeboard used in the models is not great, with the results that under resonant conditions the internal wave often overflowed the barrier, and also incident waves of large amplitude sometimes broke over the upstream face of the barrier. The amount of overflow was never great and in any case, it represents a dispersion of energy, which the barrier is designed to effect one way or another. The freeboard was deliberately limited to correspond with prototype conditions, where dimensions would be limited to reduce both cost and wind forces.

Finally, a comment should be made as to possible scale effect in the model results. The only two sources of scale effect in this case are surface tension and viscosity. The first can be neglected; but viscosity could have some effect on the resonant water movements. The damping effect of viscosity would be greater in the model than in the prototype because the model has very much smaller Reynolds number. The conclusion then, is that in resonant action the prototypes will be slightly better then predicted by the models. All the work done has been related to a prototype 120 times the size of the model, but the results can of course be transferred to any other desired scale by accepted similarity methods.

\section{CONCLUSION}

The main conclusion is that the combination of inertia and resonance in the rertical resonator reflects at least 50 per cent of the energy of waves of all periods up to about 8 seconds; and in the horizontal resonator up to about 10 seconds. This degree of reflection is thought to be sufficient for beach protection under almost all conditions and probably for a number of other' applications. The horizontal resonator is favoured for application to beach protection because of its greater range of action and its smaller heaving motion in action.

The advantages of a floating wave reflector or breakwater are quite evident. It is mobile and independent of tide. Apart from beach protection it has a variety of possibilities such as temporary protection works, seasonal harbours or supplementary protection for existing fixed harbours. For harbour purposes its cost is likely to be no more than a fraction of that of conventional fixed breakwaters.

On the other hand the limitations of this method must not be evaded. It has little effect 
de son efficacité quand sa profondeur d'immersion constitue moins de $75 \%$ de la profondeur des eaux dans lesquelles il plonge, et ce taux constitue une limite. A ce point de vue, le résonateur vertical est moins sensible, mais, par contre, il a peu d'effet sur des vagues de période dépassant les 8 secondes.

Il y a enfin lieu de noter que nos travaux, dont il vient d'être question, n'ont pas la prétention d'épuiser le sujet ni d'être complets. Il s'est agi d'une étude à deux dimensions sur un modèle à fond fixe. On envisage de nouvelles recherches avec un fond mobile et aussi à trois dimensions. Un autre point qui devra être éclairci est la façon pratique d'amarrer les brise-lames réels et les forces de rappel que l'amarrage fait naître.

Nous n'avons pas encore franchi la totalité du chemin à parcourir, mais nous avons quand même réussi à concevoir un brise-lames conforme aux principes de l'hydraulique, et en avance sur ce qui a été fait jusqu'ici. on waves of much more than 10 seconds period and could not be used on any coast where waves of extreme violence occur. The horizontal resonator loses most of its resonant action when the ratio of its submergence to the water depth is less then 0.75 and is to this extent circumscribed. The vertical resonator is not as sensitive in this respect, but has little effect on waves of more than 8 seconds period.

It should be pointed out that the work here reported is not exhaustive, nor yet complete. It is a two-dimensional study with a fixed bed. Further work is to be carried out using a movable bottom, and also in three dimensions. Another point which will clearly need attention is the method of mooring the breakwaters in practice and the restraining forces involved. The end of the road has not yet been reached, but what has ben achieved is the hydraulic design of a floating breakwater which is an advance on earlier designs.

\section{REFERENCES}

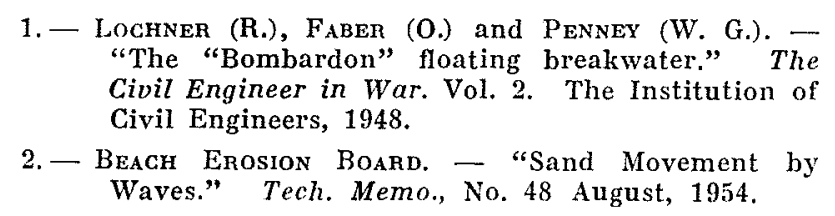
Civil Engineer in War. Vol. 2. The Institution of Civil Engineers, 1948.

2. - Beach Erosion Board. - "Sand Movement by Waves." Tech. Memo., No. 48 August, 1954.

\footnotetext{
3. - Valembois (J.). - "Investigation of the effect of resonant structures on wave propagation." Proc. Minnesota International Hydraulics Convention, 1953.

4.- Carr (J. H.). - "Mobile Breakwaters." Coastal Engincering 2, Nov. 1951.
} 
APPENDIX. - ANNEXE

Tabulated experimental results

Tableaux des résultats expérimentaux

TEST 33. - ESSAI N $N^{\circ} 33$

Observations of reflector movements with plunger stroke $1.0 \mathrm{in}$.

Mesures du mouvement du réflecteur avec une course du batteur piston de 1,0 pouce

\begin{tabular}{|c|c|c|c|c|}
\hline \multirow{2}{*}{$\begin{array}{l}h \text { in. } \\
h \text { en pouces }\end{array}$} & \multirow{2}{*}{$\begin{array}{c}\text { T sec. } \\
\text { T en secondes }\end{array}$} & \multicolumn{2}{|c|}{$\begin{array}{l}\text { REFLECTOR MOVEMENT } \\
\text { Honvement du corps refféchissant }\end{array}$} & \multirow{2}{*}{$\begin{array}{l}\text { REMARKS } \\
\text { OBSERVATIONS }\end{array}$} \\
\hline & & Horiz. & vert. & \\
\hline 3.0 & 0.40 & 0.2 & 0.2 & \\
\hline 3.0 & 0.50 & 0.5 & 0.8 & Just hits bottom \\
\hline 3.0 & 0.55 & 0.6 & 0.9 & $\begin{array}{l}\text { Tollche jllste le fond } \\
\text { Hits bottom } \\
\text { Touche le fond }\end{array}$ \\
\hline 3.0 & 0.60 & 0.6 & 0.75 & Just hits bottom \\
\hline 3.0 & 0.65 & 0.7 & 0.7 & Just hits bottom \\
\hline 3.0 & 0.74 & 0.7 & 0.7 & Hits bottom \\
\hline 3.0 & 0.84 & 0.8 & 0.6 & Hits bottom \\
\hline 3.0 & 0.94 & 0.8 & 0.6 & Just hits bottom \\
\hline 3.0 & 1.05 & 0.8 & 0.6 & Just hits bottom \\
\hline 3.5 & 0.40 & 0.2 & 0.2 & \\
\hline 3.6 & 0.50 & 0.7 & 0.4 & \\
\hline 3.5 & 0.54 & 0.6 & 0.6 & \\
\hline 3.5 & 0.60 & 0.7 & 1.0 & \\
\hline 3.5 & 0.64 & 0.6 & 0.5 & \\
\hline 3.5 & 0.70 & 0.7 & 0.6 & \\
\hline 3.5 & 0.78 & 0.7 & 0.6 & \\
\hline 3.5 & 0.88 & 0.8 & 0.5 & \\
\hline 3.5 & 1.05 & 0.9 & 0.5 & \\
\hline 4.0 & 0.42 & 0.2 & 0.2 & \\
\hline 4.0 & 0.50 & 0.6 & 0.7 & \\
\hline 4.0 & 0.57 & 0.6 & 0.7 & \\
\hline 4.0 & 0.63 & 0.7 & 0.3 & \\
\hline 4.0 & 0.69 & 0.7 & 0.5 & \\
\hline 4.0 & 0.74 & 0.8 & 0.8 & \\
\hline 4.0 & 0.88 & 0.9 & 0.65 & \\
\hline 4.0 & 1.05 & 0.9 & 0.6 & \\
\hline
\end{tabular}

TEST 33 (Contd). - ESSAI No 33 (suite)

Observations of wave reflection

Mesures de la réflexion de la houle

$h=3.5$ in. plunger stroke $=0.75 \mathrm{in}$.

$h=3,5$ pouces course du batteur piston $=0,75$ pouce

\begin{tabular}{|c|c|c|c|c|c|}
\hline \multirow{2}{*}{$\begin{array}{c}\text { T sec. } \\
\text { (secondes) }\end{array}$} & \multirow{2}{*}{$\underset{\text { (pouces) }}{2 a_{1} \mathrm{in} .}$} & \multirow{2}{*}{$\begin{array}{l}2 a_{3} \text { in. } \\
\text { (pouces) }\end{array}$} & \multicolumn{2}{|c|}{$\begin{array}{l}\text { REFLECIOR MOVENENT } \\
\text { Mouvement du réflecteur }\end{array}$} & \multirow{2}{*}{$\begin{array}{c}\text { REMARKS } \\
\text { OBSEHVATIONS }\end{array}$} \\
\hline & & & Horiz. & Vert. & \\
\hline 0,48 & 0.68 & 0.28 & 0.2 & 0.8 & \\
\hline 0.56 & 0.70 & 0.29 & 0.3 & 0.6 & \\
\hline 0.68 & 0.62 & 0.28 & 0.4 & 0.2 & \\
\hline 0.79 & $0.4 ! 5$ & 0.31 & 0.5 & 0.6 & \\
\hline 0.90 & 0.41 & 0.38 & 0.6 & 0.5 & \\
\hline 1.02 & 0.41 & 0.40 & 0.5 & 0.5 & \\
\hline
\end{tabular}


TEST $34 .-$ ESSAI N" 34

$h=3.35$ in. $\quad$ plunger stroke $=0.69 \mathrm{in}$.

$h=3,35$ pouces course du batteur piston $=0,69$ pouce

\begin{tabular}{|c|c|c|c|c|c|}
\hline \multirow{2}{*}{$\begin{array}{c}\text { Tsec. } \\
\text { (secondes) }\end{array}$} & \multirow{2}{*}{$\underset{\text { (pouces) }}{2 a_{1} \text { in. }}$} & \multirow{2}{*}{$\begin{array}{l}2 a_{3} \text { in. } \\
\text { (pouces) }\end{array}$} & \multicolumn{2}{|c|}{$\begin{array}{l}\text { REFLECTOR MOVEMENT } \\
\text { Mourement du reflecteur }\end{array}$} & \multirow{2}{*}{$\begin{array}{l}\text { REMARKS } \\
\text { OHSERVATIONS }\end{array}$} \\
\hline & & & Horiz. & Vert. & \\
\hline 0.44 & 0.53 & 0.23 & 0.2 & 0.1 & \\
\hline 0.55 & 0.55 & 0,33 & 0.2 & 0.1 & \\
\hline 0.64 & 0.55 & 0.40 & 0.3 & 0.2 & \\
\hline 0.75 & 0.48 & 0.29 & 0.4 & 0.4 & \\
\hline 0.85 & 0.41 & 0.25 & 0.4 & 0.4 & \\
\hline 0.95 & 0.37 & 0.29 & 0.4 & 0.3 & \\
\hline 1.10 & 0.33 & 0.31 & 0.3 & 0.3 & \\
\hline
\end{tabular}

TEST 35. - ESSAI N" 35

$h=3.75 \mathrm{in.} \quad$ plunger stroke $=0.69 \mathrm{in}$.

$h=3,75$ pouces course du batteur piston $=0,69$ pouce

\begin{tabular}{|c|c|c|c|c|c|}
\hline \multirow{2}{*}{$\begin{array}{c}\text { T sec. } \\
\text { (secondes) }\end{array}$} & \multirow{2}{*}{$\begin{array}{l}2 a_{1} \mathrm{in} . \\
\text { (pouces) }\end{array}$} & \multirow{2}{*}{$\begin{array}{l}2 a_{3} \text { in. } \\
\text { (pouces) }\end{array}$} & \multicolumn{2}{|c|}{$\begin{array}{l}\text { REFLECTOR MOVEMENT } \\
\text { Mouvement du réflecteur }\end{array}$} & \multirow{2}{*}{$\begin{array}{c}\text { REMARKS } \\
\text { OBSEIVATIONS }\end{array}$} \\
\hline & & & Horiz. & Vert. & \\
\hline 0.44 & 0.55 & 0.20 & 0.2 & 0.1 & \\
\hline 0.55 & 0.55 & 0.30 & 0.3 & 0.2 & \\
\hline 0.66 & 0.52 & 0.34 & 0.4 & $0 . \overline{5}$ & \\
\hline 0.78 & 0.45 & 0.28 & 0.4 & 0.6 & Spilling over \\
\hline 0.90 & 0.32 & 0.25 & 0.4 & 0.5 & Deversement. \\
\hline 1.05 & 0.31 & 0.30 & 0.4 & 0.4 & \\
\hline
\end{tabular}

TEST 36. - ESSAI $\mathrm{N}^{\circ} 36$

$h=4.0$ in. plunger stroke $=0.69 \mathrm{in}$.

$h=4,0$ ponces course du batteur piston $=0,69$ pouce

\begin{tabular}{|c|c|c|c|c|c|}
\hline \multirow{2}{*}{$\begin{array}{c}\text { T sec. } \\
\text { (secondes) }\end{array}$} & \multirow{2}{*}{$\begin{array}{l}2 a_{1} \text { in } \\
\text { (pouces) }\end{array}$} & \multirow{2}{*}{$\begin{array}{l}2 a_{3} \text { in. } \\
\text { (pouces) }\end{array}$} & \multicolumn{2}{|c|}{$\begin{array}{l}\text { REFLECTOR MOVEMENT } \\
\text { Mouvement du réflecteur }\end{array}$} & \multirow{2}{*}{$\begin{array}{l}\text { REMARKS } \\
\text { OBSERVATIONS }\end{array}$} \\
\hline & & & Horiz. & Vert. & \\
\hline 0.43 & 0.53 & 0.18 & 0.2 & 0.1 & \\
\hline 0.56 & 0.62 & 0.30 & 0.3 & 0.3 & \\
\hline 0.69 & 0.56 & 0.29 & 0.4 & 0.6 & Spilling over \\
\hline 0.80 & 0.45 & 0.34 & 0.4 & 0.6 & Spilling over \\
\hline 0.94 & 0.40 & 0.37 & 0.5 & 0.4 & Spilling over \\
\hline 1.10 & 0.36 & 0.36 & 0.5 & 0.4 & Déversement \\
\hline
\end{tabular}


TEST 37. - ESSAI N ${ }^{\circ} 37$

$h=4.5 \mathrm{in}$. plunger stroke $=0.69 \mathrm{in}$.

$h=4,5$ pouces course du batteur piston $=0,69$ pouce

\begin{tabular}{|c|c|c|c|c|c|}
\hline \multirow{2}{*}{$\begin{array}{c}\text { T sec. } \\
\text { (secondes) }\end{array}$} & \multirow{2}{*}{$\underset{\text { (pouces) }}{2 a_{1} \mathrm{in.}}$} & \multirow{2}{*}{$\begin{array}{l}2 a_{3} \text { in. } \\
\text { (pouces) }\end{array}$} & \multicolumn{2}{|c|}{$\begin{array}{l}\text { REFLECTOR MOVEMENT } \\
\text { Mouvement du réflecteur. }\end{array}$} & \multirow{2}{*}{$\begin{array}{c}\text { REMARKS } \\
\text { OBSERVATIONS }\end{array}$} \\
\hline & & & Horiz. & Vert. & \\
\hline 0.43 & 0.63 & 0.22 & 0.2 & 0.2 & \\
\hline 0.53 & 0.59 & 0.38 & 0.4 & 0.2 & \\
\hline 0.66 & 0.55 & 0.35 & 0.4 & 0.8 & Spilling over \\
\hline 0.78 & 0.45 & 0.37 & 0.4 & 0.8 & \\
\hline 0.90 & 0.41 & 0.38 & 0.6 & 0.6 & \\
\hline
\end{tabular}

TEST 38. - ESSAI No38

$h=4.5$ in. plunger stroke $=1.06 \mathrm{in}$.

$h=4,5$ pouces course du batteur piston $=1,06$ pouce

\begin{tabular}{|c|c|c|c|c|c|}
\hline \multirow{2}{*}{$\begin{array}{c}\text { Tsec. } \\
\text { (secondes) }\end{array}$} & \multirow{2}{*}{$\begin{array}{c}2 a_{1} \mathrm{in} . \\
\text { (pouces) }\end{array}$} & \multirow{2}{*}{$\begin{array}{l}2 a_{3} \text { in. } \\
\text { (pouces) }\end{array}$} & \multicolumn{2}{|c|}{$\begin{array}{l}\text { REFLECTOR MOVEMENT } \\
\text { Mouvement du réflecteur }\end{array}$} & \multirow{2}{*}{$\begin{array}{l}\text { REMARKS } \\
\text { OBSERVATIONS }\end{array}$} \\
\hline & & & Horiz. & Vert. & \\
\hline 0.41 & 0.45 & 0.29 & 0.2 & 0.1 & \multirow{5}{*}{$\begin{array}{l}\text { Spilling over } \\
\text { Spilling over } \\
\text { Déversement }\end{array}$} \\
\hline 0.51 & 0.92 & 0.55 & 0.5 & 0.2 & \\
\hline 0.62 & 0.81 & 0.51 & 0.6 & 0.6 & \\
\hline 0.75 & 0.73 & 0.60 & 0.7 & 1.0 & \\
\hline 0.88 & 0.71 & 0.69 & 0.9 & 0.9 & \\
\hline
\end{tabular}

TEST 39. - ESSAI $\mathrm{N}^{\circ} 39$

$h=4.0$ in. plunger stroke $=1.06 \mathrm{in}$.

$h=4,0$ pouces course du batteur piston $=1,06$ pouce

\begin{tabular}{|c|c|c|c|c|c|}
\hline \multirow{2}{*}{$\begin{array}{c}\text { 'T sec. } \\
\text { (secondes) }\end{array}$} & \multirow{2}{*}{$\underset{\text { (pouces) }}{2 a_{1} \text { in. }}$} & \multirow{2}{*}{$\begin{array}{l}2 a_{3} \text { in. } \\
\text { (pouces) }\end{array}$} & \multicolumn{2}{|c|}{$\begin{array}{l}\text { REFLECIOR MOVEMENT } \\
\text { Houvement du réflecteur }\end{array}$} & \multirow{2}{*}{$\begin{array}{l}\text { REMARKS } \\
\text { OBSERVATIONS }\end{array}$} \\
\hline & & & Horiz. & Vert. & \\
\hline 0.44 & 0.93 & 0.31 & 0.4 & 0.2 & \\
\hline 0.54 & 0.82 & 0.41 & 0.4 & 0.2 & \\
\hline 0.64 & 0.75 & 0.44 & 0.6 & 0.4 & Spilling over \\
\hline 0.74 & 0.69 & 0.41 & $0 . \vec{i}$ & 0.6 & Spilling over \\
\hline 0.84 & 0.63 & 0.45 & 0.6 & 0.7 & 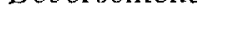 \\
\hline 1.00 & 0.58 & 0.53 & 0.7 & 0.5 & \\
\hline
\end{tabular}


TEST 40. - ESSAI N" 40

$h=3.75 \mathrm{in.} \quad$ plunger stroke $=1.06 \mathrm{in}$.

$h=3,75$ pouces course du batteur piston $=1,06$ pouce

\begin{tabular}{|c|c|c|c|c|c|}
\hline \multirow{2}{*}{$\begin{array}{c}\mathrm{T} \text { sec. } \\
\text { (secondes) }\end{array}$} & \multirow{2}{*}{$\begin{array}{c}2 a_{1} \text { in. } \\
\text { (pouces) }\end{array}$} & \multirow{2}{*}{$\begin{array}{l}2 a_{3} \text { in. } \\
\text { (pouces) }\end{array}$} & \multicolumn{2}{|c|}{$\begin{array}{l}\text { RFFLECTOR MOVEMENT } \\
\text { Mouvement du reflecteur }\end{array}$} & \multirow{2}{*}{$\begin{array}{c}\text { REMARKS } \\
\text { OBSERVATIONS }\end{array}$} \\
\hline & & & Ilori\%. & Vert. & \\
\hline 0.44 & 0.93 & 0.27 & 0.2 & 0.2 & \\
\hline 0.54 & 0.82 & 0.45 & 0.5 & 0.2 & Spilling over \\
\hline 0.63 & 0.68 & 0.46 & $0 . \overline{5}$ & 0.5 & Spilling over \\
\hline 0.75 & 0.60 & 0.32 & 0.6 & 0.6 & Spilling over \\
\hline 0.82 & 0.38 & 0.38 & 0.6 & 0.7 & \\
\hline 1.00 & 0.48 & 0.44 & 0.5 & 0.7 & \\
\hline
\end{tabular}

TEST 41. - ESSAI N" 41

$h .=3.5$ in. plunger stroke $=1.06 \mathrm{in}$

$h=3,5$ pouces course du batteur piston $=1,06$ pouce

\begin{tabular}{|c|c|c|c|c|c|}
\hline \multirow{2}{*}{$\begin{array}{c}\text { T sec. } \\
\text { (secondes) }\end{array}$} & \multirow{2}{*}{$\underset{\text { (pouces) }}{2 a_{1} \text { in. }}$} & \multirow{2}{*}{$\frac{2 a_{3} \text { in. }}{\text { (pouces) }}$} & \multicolumn{2}{|c|}{$\begin{array}{l}\text { MEFLECTOR MOVEMENT } \\
\text { Mouvement du réflecteur }\end{array}$} & \multirow{2}{*}{$\begin{array}{c}\text { REMARKS } \\
\text { OBSERVATIONS }\end{array}$} \\
\hline & & & Horiz. & Vert. & \\
\hline 0.42 & 0.90 & 0.29 & 0.2 & 0.1 & \\
\hline 0.52 & 0.82 & 0.32 & 0.4 & 0.8 & \\
\hline 0.63 & 0.62 & 0.42 & 0.5 & 0.3 & Spilling over \\
\hline 0.74 & 0.61 & 0.32 & 0.5 & 0.4 & Spilling over \\
\hline 0.86 & 0.57 & 0.39 & 0.6 & 0.7 & \\
\hline 1.00 & 0.48 & 0.42 & 0.7 & 0.6 & \\
\hline
\end{tabular}

TEST 42. - ESSAI N"42

$h=3.35 \mathrm{in} . \quad$ plunger stroke $=1.06 \mathrm{in}$.

$h=3,35$ ponces course du batteur piston $=1,06$ pouce.

\begin{tabular}{|c|c|c|c|c|c|}
\hline \multirow{2}{*}{$\begin{array}{c}\text { T sec. } \\
\text { (secondes) }\end{array}$} & \multirow{2}{*}{$\begin{array}{c}2 a_{1} \mathrm{in} . \\
\text { (pouces) }\end{array}$} & \multirow{2}{*}{$\begin{array}{l}2 a_{3} \text { in. } \\
\text { (pouces) }\end{array}$} & \multicolumn{2}{|c|}{$\begin{array}{l}\text { REFLECTOR MOVEMENT } \\
\text { Mouvement du réflecteur }\end{array}$} & \multirow{2}{*}{$\begin{array}{c}\text { REMARKS } \\
\text { OBSERYATIONS }\end{array}$} \\
\hline & & & Horiz. & Vert. & \\
\hline 0.42 & 0.88 & 0.32 & 0.2 & 0.1 & \\
\hline 0.52 & 0.82 & 0.39 & 0.3 & 0.2 & \\
\hline 0.62 & 0.67 & 0.44 & 0.5 & 0.2 & Spilling over \\
\hline 0.74 & 0.60 & 0.35 & 0.3 & 0.5 & $\begin{array}{l}\text { Spilling over- } \\
\text { hitting bottom } \\
\text { Deversement ef } \\
\text { lonche le fond. }\end{array}$ \\
\hline 0.88 & 0.59 & 0.37 & 0.6 & 0.6 & \\
\hline 1.00 & 0.48 & 0.42 & 0.5 & 0.4 & \\
\hline
\end{tabular}

